\title{
TRANSITIONING TO COMMUNICATIVE ACTIVITIES IN TEACHING ENGLISH AS A FOREIGN LANGUAGE IN THE DOMINICAN REPUBLIC
}

\author{
Transición a actividades comunicativas en la enseñanza de Inglés como \\ Lengua Extranjera en la República Dominicana
}

Alberto Martínez-Gómez ${ }^{1}$

albertomartinez@docente.utesa.edu

${ }^{1}$ Universidad Tecnológica de Santiago, República Dominicana

Fecha de recepción: 18/01/2020

Fecha de aprobación: 12/05/2020

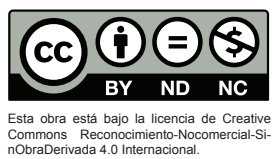

ISSN (impreso): 2636-2139

ISSN (en línea): 2636-2147

Sitio web: https://revistas.isfodosu.edu.do/recie

\section{Abstract}

In the last decade, the Communicative Approach has taken an important position within the English language teaching world. Many countries have abandoned their traditional teaching methods to implement this approach. The objectives of this research were to analyze the transitioning to communicative activities in Teaching English as a foreign language in the Dominican Republic, to identify the communicative activities to which the students were more receptive, to research students' attitudes while developing communicative activities, and lastly, to analyze new strategies for successful communicative activities. To carry out the investigation, three interventions were carried out in the classroom where activities such as role-play, group work, mingle, information transfer, opinion sharing, and information gap were implemented. Two interviews were administered to learners. Participant observation was implemented as well as the teacher's diary and note-taking as a way of record the events. Interviews revealed that students had a great disposition towards group work as well as having conversations and activities that involved giving opinions. They also showed that close attention should be paid to activities that involve speaking in front of the class as they raised students' stress levels. According to students' performance and answers during the sessions, group work, information gap, and opinion sharing activities activated their motivation to a greater extent. Modeling and giving clear instructions was fundamental to overcome linguistic gaps that emerged during the sessions. The progressive integration of the target language was more convenient while implementing communicative activities.

Keywords: communicative activities, communicative approach, Dominican Republic, English, foreign language, transitioning.

\section{Resumen}

En la última década, el enfoque comunicativo ha tomado una posición importante dentro del mundo de la enseñanza del idioma inglés. Muchos países han abandonado sus métodos tradicionales a fin de implementar dicho enfoque. Esta investigación tuvo como objetivo analizar la transición a actividades comunicativas en la enseñanza de inglés como lengua extranjera en la República Dominicana, identificar las actividades comunicativas a las cuales los estudiantes eran más receptivos, investigar las actitudes de los estudiantes al desarrollar dichas actividades $y$, por último, analizar nuevas estrategias para tener actividades comunicativas exitosas. Para llevar a cabo la investigación, se realizaron tres intervenciones en el aula aplicando actividades como juego de roles, trabajo grupal, actividades de falta de información, actividades de intercambio de opiniones, actividades de mezcla y actividades de transferencia de información. Se administraron dos entrevistas y se implementó la observación participante, así como el diario del maestro para registrar los eventos. Las entrevistas revelaron que los estudiantes tenían una gran disposición hacia el trabajo en grupo. También mostraron que las actividades que implican hablar en frente de la clase aumentan el nivel de estrés de los estudiantes. Según el rendimiento y las respuestas de los estudiantes, el trabajo en grupo, las actividades de búsqueda de información y las actividades de intercambio de opiniones activaron su motivación en mayor medida. Modelar y dar instrucciones claras fue fundamental para superar las brechas lingüísticas que surgieron durante las sesiones. Una integración progresiva del idioma de destino fue más conveniente al implementar actividades comunicativas.

Palabras clave: actividades comunicativas, inglés, lengua extranjera, método comunicativo, República Dominicana, transición. 


\section{Introduction}

Little emphasis had been given to English language teaching in the Dominican Republic. Regularly, students were and some still are taught English by teachers who are not specialized in the area. For the first time, in 2014, the Ministry of Education of the Dominican Republic (MINERD) started hiring English teachers through a rigorous competitive selection process. It is worth to point out that this selection process was part of the Categorization by teaching positions in the context of the development of the teaching career in the Dominican Republic: A horizontal perspective published in 2014 by the MINERD. This document contained the standards for selection, induction, training, and evaluation of Dominican teachers in the classroom (pp. 40-125).

The Grammar-Translation Method (GTM) had been the dominant approach used to teach English in different private English schools or "Institutes" as they are normally called. According to Larsen-Freeman and Anderson (2011, p. 32), "this method was used to help students read and appreciate foreign language literature" in which the learner translated pieces of text from one language to another. Richards and Rodgers (2014, p. 6) stated that GTM "approaches the language first through a detailed analysis of its grammar rules" with the finality of translating sentences and texts out and into the target language. Years after, it was noticed that GTM was not enough for real language use or to develop communicative competence. As the majority of current English teachers were formed through this approach, that is the current methodology they use to teach in their classrooms.

In the last two years, it has been noticed that the materials and course books that the Ministry of Education provides are oriented to a communicative way of teaching, but teachers lack training in implementing the communicative approach. In 2017, MINERD implemented a training course called "English for Communicative Language Teaching" with the assistance of the World Learning Organization and the Dream Project, where teachers learned that En- glish could be taught in English and that interesting and funny activities could be done in the language classroom. Teachers also learned many strategies and ways on how to teach students more communicatively. Although the teacher training in regard to the Communicative Method has started, a wider range of coverage is still needed.

In the Dominican Republic, English Language Teaching (ELT) is not focused on communicative activities and as a consequence, it was necessary to investigate how the transition from traditional (grammar-translation) to more communicative activities would be, taking into account certain factors and variables such as identifying the communicative activities to which students were more receptive, investigating students' attitudes while developing communicative activities, and analyzing new strategies to have successful communicative activities.

History has shown that a minimal variation of the way we normally do things can create an impact on our comfort zone and how the world is seen. Changes are not easy and there is always resistance and frustration during the process of adjusting to new teaching methods. This study can benefit teachers who start implementing the communicative approach because they would see students' attitudes and reactions during the transitional process.

\section{Research Objectives}

Overall, this research aims at analyzing the transitioning from traditional methods to communicative activities in teaching English as a Foreign Language in the Dominican Republic. In order to reach these objectives, the researcher tries to answer the following research questions:

1. What communicative activities are students more receptive to?

2. What are students' attitudes when developing communicative activities?

3. What new strategies could be used to have successful communicative activities? 


\section{Literature Review}

\subsection{Communicative Language Teaching (CLT)}

The language teaching field has been influenced by two interacting forces: One comes from the outside of the profession and the other from the inside (Richards \& Rodgers, 2014). The world has changed, and English has become the global language. This is the reason why in the last decades there has been a great effort to discover the best ways to learn a language, in this case, English (Crystal, 2012).

According to Richards and Rodgers (2014), proponents of the CLT did not describe it as a method but as an approach "that aimed to make communicative competence the goal of language teaching and to develop procedures for the teaching of the four language skills that acknowledge the interdependence of language and communication" (p. 85). It is important to know for some people, CLT means a little more than the integration of grammar and function, but for others, it is just an approach where students work interactively in groups, using available resources to solve tasks. Arzamendi et al. (2016) says that it is a set of approaches, rather than a method.

Some of the first forms of Communicative Language Teaching tended to take apart any open inclusion of structure of the language in the syllabus because it was feared that it would result in the rejection and bad acceptance that the previous methods, approaches, and methodologies had. The syllabus designers founded their theoretical ideas in the work of Prabhu (1987), where he argued that the knowledge we need to use a language is complicated enough to be dealt with by simply teaching grammar. The main theory in CLT is that learners have to develop their communicative competence, which is the ability to know not only grammatical structures, but also the appropriate language use in given situations or social contexts (Savignon, 2017).

\subsection{Communicative Activities}

Wan (1990) states that communicative activities are the techniques used to involve learners with the target language and to do so, these activities should be purposeful and interactive. Wan, who carried out an investigation where drama activities were applied, suggested that communicative activities should not be used in isolation but in combination with others. The most used communicative activities are information-gap, jigsaw, role-play, task-completion, opinion-sharing, information-transfer, reasoning-gap, and group work (Richards \& Rodgers, 2014). It is worth to mention that the English language teaching and learning process can be done affectively if communicative activities are implemented (Muhas$\sin , 2016)$.

According to Owen and Razali (2018), Libyan students faced difficulties in learning English, but with the implementation of communicative activities such as information gaps and games, they increased their language performance. They also state that communicative activities should be chosen taking into account the context and students' needs. These activities need to be focused on practicing and using the language rather than lectures about the language (Nyinondi et al., 2017). In terms of activities and strategies, Kwon (2017) tells us that special attention should be paid to group work activities as they promote the communicative competence. He also encourages to "provide quality authentic materials and activities that simulate authentic language contexts for language usage" (p. 123).

\subsection{Roles of teachers, students, and materials in communicative Language Teaching}

The role of the teacher is an innovative aspect of CLT. From being the center of attention and the controller of the whole process, now the teacher is simply considered an advisor, manager, and facilitator in the language classroom. Other linguists such as Larsen-Freeman (2011) and Richards and Rodgers (2014) use the word "monitor" to define the teacher as the person in charge of keeping track of the communicative activities in the classroom. Nowadays, students are active agents in the learning and teaching process; that is, subjects who take responsibility for their learning. The main role of teaching materials is the promotion of language use in a 
communicative way. There are three principal types of materials in the CLT world: these are task-based, text-based and realia (Arzamendi et al., 2016).

\subsection{Researches in the Application of Communicative Language Teaching}

Ahmad and Rao (2012) in their research entitled Does it Work? Implementing Communicative Language Teaching Approach in EFL Context concluded that the implementation of the communicative activities is complex, however, very effective, even more than traditional ones, but only if conducted properly and at the same time taking into account the local circumstances and above all, students' interests. In 2013, Ahmad and Rao conducted another research called Applying Communicative Approach in Teaching English as a Foreign Language: A Case Study of Pakistan in which the results showed that the CLT approach was more suitable for teaching English as a foreign language than the traditional method which was the Grammar Translation Method (GTM). They also clarified that suitable conditions, learning resources, and teacher training were necessary to have good results.

Chan and Chen (2010) enlist a series of factors that promote and/or hinder the implementation of communicative activities in a Taiwanese college. In his results he explains that students showed resistance to group work activities. He suggests using simple language, visual aid and different resources. Vongxay (2013) in his research The implementation of Communicative Language teaching (CLT) in an English Department in a Lao Higher Educational Institution: A Case Study, concluded that communicative activities produced better results when they were implemented with medium to high level of proficiency while low-proficiency students were more likely to show some type of resistance. According to Rahmanwati (2018), the implementation of communicative activities in Indonesian classrooms was not effective because teachers took grammar for granted and only focused on speaking activities.

Algwil (2019) details some strategies to have engaging communicative activities such as giving extra tasks to those students who finish earlier, discussions in pairs or small groups, and providing students enough time to talk. However, he mentioned that sometimes when working in groups, students may not like others with whom they are grouped. Denkci Akkas and Coker (2016) concluded that "authentic or authentic-like materials with audio visual components engage learners in purposeful and meaningful use of language" (p. 82). Kwon (2017) suggests that "teachers must provide effective modeling of communicative techniques in use and allot time for students to practice those techniques" (p. 124).

Students' attitudes and motivation to work with communicative activities depend a lot on teacher training and the attitude the teacher shows towards such type of activities. If students realize that teachers do not believe in what they are doing, then those activities will not be successful (Denkci Akkas \& Coker, 2016). Herouach et al. (2020) stated that students' attitudes towards CLT activities were positive because those activities were the ones they preferred their teachers to use. However, on their research with senior high schools in Bengkalis, Malik and Gunawan (2018) said that students lacked of motivation which became an issue to implement CLT activities.

\section{Methodology}

The research type adopted for this investigation was the "Action Research". According to Madrid (2016) and McNiff (2017), Action Research can be used by the classroom teacher for a variety of purposes: it can be used as a way of learning about learners, about our teaching and its effectiveness, and as a way of monitoring and evaluating innovation. Kemmis et al. (2014) explain that Action Research has three main characteristics: the teacher is the one in charge of the investigation, it is a collaborative work, and its finality is to improve teaching practice.

This research was carried out with a qualitative approach, which is a scientific research method based on observation. It covers the areas that quantitative research can't. Instead of paying attention to countable data, qualitative research focuses on those fac- 
tors that can't be counted or measured, e.g., decision making, characteristics, behaviors, and others. Most of the investigations carried out in social work, political science and education are done with this type of research (Neuman, 2014). In qualitative research, the researcher is the main analyzer and data collector and it requires the researcher to get acquainted with the site, people or setting to do an adequate observation.

\subsection{Population and Sample}

This project was implemented in a primary-level public school called "Los Rieles II", located in the San Marcos community in the city of Puerto Plata. The school had 468 students, a mixture of males and females. $90 \%$ of students came from San Marcos and $10 \%$ came from other communities. In order to carry out this investigation, a sixth-grade group was chosen. The group consisted of 30 students: 16 females and 14 males. The average age of the students was 11 years old. They had different capacity levels in the English language which made them a mixed-ability group. Some of them were at an elementary level (A2), while others were in a low-intermediate level (B1). Students received 4 hours of English class weekly because they belonged to the "extended shift modality", which comprised eight hours of class daily.

\subsection{Research Tools}

As this investigation is an Action Research with a qualitative approach, three interventions were done to implement the communicative approach with sixth-grade students. During these interventions, two types of interviews were used: one structured and the other semi-structured. Participant observation was also used together with the note-taking technique as a way of recording the events during the class interventions. The terms "interventions" and "class sessions" are used interchangeably in this research paper.

\subsubsection{Cycles and sequence of investigation}

The action research cycle was repeated three times during the study (see table 1). The first cycle started with the structure interviews as a way of exploring the field of investigation. After these interviews, a lesson plan for the first intervention was prepared. The lesson plan was put into action and at the same time, the researcher started the observation and data collection. In the reflection phase, data was analyzed and according to the findings, the second cycle started with a revision of the plan.

Table 1. Synthesis of the cycles of investigation of the research

\begin{tabular}{|c|c|c|c|}
\hline Phases & Cycle 1 & Cycle 2 & Cycle 3 \\
\hline Planning & $\begin{array}{l}\text { Structured interviews } \\
\text { Lesson Plan }\end{array}$ & $\begin{array}{l}\text { Revision of the plan } \\
\text { Lesson plan }\end{array}$ & $\begin{array}{l}\text { Revision of the plan } \\
\text { Lesson plan }\end{array}$ \\
\hline Action & Intervention 1 & Intervention 2 & Intervention 3 \\
\hline Observation & $\begin{array}{l}\text { By the researcher during the } \\
\text { intervention } \\
\text { Semi-structured interviews } \\
\text { Data collection }\end{array}$ & $\begin{array}{l}\text { By the researcher } \\
\text { during the interven- } \\
\text { tion } \\
\text { Data collection }\end{array}$ & $\begin{array}{l}\text { By the researcher during the } \\
\text { intervention } \\
\text { Semi-structured interviews } \\
\text { Data collection }\end{array}$ \\
\hline Reflection & $\begin{array}{l}\text { Data analysis of Interview and } \\
\text { observation }\end{array}$ & $\begin{array}{l}\text { Data analysis of ob- } \\
\text { servation }\end{array}$ & $\begin{array}{l}\text { Data analysis of Interview and } \\
\text { observation }\end{array}$ \\
\hline
\end{tabular}

Note: Created by researchers. 
The following chart will show the interventions' sequence during the whole study along with the communicative activities to be implemented.

Table 2. Interventions' sequence and communicative activities

\begin{tabular}{|c|c|c|}
\hline Interventions & Dates & Activities \\
\hline 1 & May $08^{\text {th }}$ & $\begin{array}{l}\text { - Information gap } \\
\text { - Role play } \\
\text { - Group work }\end{array}$ \\
\hline 2 & May $22^{\text {nd }}$ & $\begin{array}{l}\text { - Group work } \\
\text { - Mingle } \\
\text { - Information transfer }\end{array}$ \\
\hline 3 & June $05^{\text {th }}$ & $\begin{array}{l}\text { - Opinion sharing } \\
\text { - Role play }\end{array}$ \\
\hline
\end{tabular}

Note: Created by researchers.
In the third cycle of investigation, the researcher intended to implement the topic of feelings and emotions where the focus was on opinion sharing and role-play activities. The planning phase started with the revision of the action according to the needs identified at the end of the third cycle. In the action phase, the plan was implemented, and the data was gathered for its posterior analysis and the elaboration of the conclusions (see Table 3 and Table 4).

Table 3. Phases and time of third cycle of investigation

\begin{tabular}{ll}
\hline Phase & Time \\
\hline Planning & May $29^{\text {th }}-$ June $04^{\text {th }}$ \\
\hline Action and observation & June $05^{\text {th }}$ \\
\hline Reflection & June $06^{\text {th }}-$ June $22^{\text {nd }}$ \\
\hline
\end{tabular}

Note: Created by researchers.

Table 4. Procedures of the third cycle of investigation

\begin{tabular}{|c|c|c|}
\hline Phase & Activities & Procedures \\
\hline Planning & Action plan elaboration & $\begin{array}{l}\text { - Revision of the plan } \\
\text { - Define plan objectives } \\
\text { - Design lesson plan }\end{array}$ \\
\hline Action and observation & $\begin{array}{l}\text { Implementation of action plan } \\
\text { Data collection }\end{array}$ & $\begin{array}{l}\text { - Apply the plan } \\
\text { - Observation } \\
\text { - Note-taking } \\
\text { - Interviews }\end{array}$ \\
\hline Reflection & Data analysis & $\begin{array}{l}\text { - Categorization } \\
\text { - Codifying } \\
\text { - Triangulation } \\
\text { - Interpretation }\end{array}$ \\
\hline
\end{tabular}

Note: Created by researchers.

\subsection{Data Collection}

\subsubsection{Interviews}

The structured interviews were applied to 10 participants who were randomly selected from the group. These interviews were applied before starting the first intervention. Participants were invited, separately, to the school library where the researcher explained the purpose of it. The researcher showed them the interview form which contained six close-ended questions they had to answer. Participants were assured that their names would not be published and they were also asked to keep confidentiality of the answers they gave. Interviewees were asked permission to be voice-recorded with a smartphone. These interviews were conducted in Spanish and each one lasted from 
7 to 13 minutes. The objective of the interviews was to identify the classroom activities students liked and the attitudes they had towards such activities.

The semi-structured interviews were applied to 10 participants who were randomly chosen. These interviews were conducted at the end of the first and third intervention. Five participants were interviewed at the end of the first intervention and the other five were interviewed at the end of the third one. These interviews followed the same protocol as the structured ones: participants were invited to meet the researcher individually, the purpose of the interviews was explained to them, and there was a confidentiality agreement between the researcher and the participants. The interviews' form contained five open-ended questions which were shown and discussed with the participants. Interviewees were asked permission to be voice-recorded with a smartphone. Each interview lasted from 7 to 13 minutes. The objective of these interviews was to identify the perception and receptivity students had towards the communicative activities implemented during the class sessions.

\subsubsection{Participant Observation and Notetaking}

In order to carry out this research, three interventions were applied in which different communicative activities were implemented. The participant observation method was used to collect data. During and at the end of every intervention, the researcher recorded the events observed through the note-taking technique. Notes were taken to gather information about how the procedures worked and how students reacted while working with communicative activities.

\subsection{Data Analysis}

For the analysis, both interviews were transcribed (these transcriptions were revised twice to avoid errors or omissions of important information). The thematic analysis was used to identify themes in the data collected from the interviews and the observations. The data was organized, reduced, and separated into small units of texts. The units were categorized and codified to have a better understanding of the findings. This process of categorizing and codifying was repeated after each cycle of the action research. As Hernández Sampieri et al. (2014) recommend, data triangulation was used to verify similarities and inconsistencies and this is what was done with the data from the interviews and observations. During the analysis process, saturation was used to know when to stop creating new categories as they became redundant or repetitive. During the analysis, seven main categories emerged and remained. These categories along with their codes can be seen in table 5 .

\section{Table 5. Example of categories emerged during the investigation}

\begin{tabular}{ll}
\hline Categories & Codes \\
\hline Class Opinion & CO \\
\hline Students' learning preferences & SLP \\
\hline Interaction in the target language & ITL \\
\hline Disposition to participate & DTP \\
\hline Class activities & CA \\
\hline Teaching strategies & TS \\
\hline Preferred activities & PA \\
\hline
\end{tabular}

Note: Created by researchers.

\section{Results}

The main objective of this research was to analyze the transitioning process from traditional methods to communicative activities in teaching English as a foreign language in the Dominican Republic. In order to do so, three research questions were formulated. These questions are answered in the following lines according to the findings of the research.

\subsection{Results of research question one}

Research question one investigated the communicative activities to which students were more receptive. During the data analysis, three main categories emerged to answer this question (all the categories can be seen in table 5). The categories were: 1) preferred activities (PA), 2) class activities (CA), and 3) class opinions (CO). 


\section{Preferred Activities (PA)}

In a first moment, many answers were received from the structured interviews implemented before the first intervention. All students were asked about the type of activity they liked. The answers were varied although there was a tendency to incline for dramas and working in groups. Some of the answers are contained in the following table.

Table 6. Some of the structured interviews' answers

\begin{tabular}{cl}
\hline Student (S) & Answer \\
\hline S1 & "I like dramas in restaurants" \\
\hline S3 & "To work withmy friends" \\
\hline S4 & "I like presentations" \\
\hline S7 & "working in groups is nice" \\
\hline S10 & "I like to act but easy things" \\
\hline
\end{tabular}

Note: Created by researchers.

The semi-structured interviews also helped identifying the types of activities that students preferred. In these interviews there was a question which helped confirm what it was observed in the structured interviews and the class observation. The question was: "what did you like the most from today's class?" See some of the answers in the following table.

Table 7. Some of the semi-structured interviews' answers

\begin{tabular}{cl}
\hline Student (S) & Answer \\
\hline S1 & "the dramas we did" \\
\hline S4 & "when we worked together" \\
\hline S5 & "I liked when we worked in a group" \\
\hline S7 & "to say what I was thinking" \\
\hline S9 & "when we imitated the animals" \\
\hline
\end{tabular}

Note: Created by researchers.

\section{Class Activities (CA)}

In the first intervention, students seemed a little confused because everything was in English but after the vocabulary was provided, they started responding.
There was an activity where they had to start a conversation with a classmate and then introduce the person to the group, and all the students participated actively. In the second intervention, they had to convert some information into a sentence using the address, which was the topic of the lesson. Students got confused and started writing the sentences incorrectly. had to explain again so they could understand the proper way to organize and convert the information.

The group work activity which was combined with the information gap, in intervention 1, was easier to implement than the information transfer activity mentioned above. The mingle activity was very difficult to develop because the majority of the students didn't want to stand up and ask others for their address. Some of the students who stood up didn't take it so seriously to the point that they depended on Spanish to ask for the information. Others just wanted to talk to a specific person who was their friend. In the third intervention, students had to do a role play which consisted of imitating animals' sounds. The activity worked well and students were motivated. During this intervention I also noticed that students were active at the moment of giving their opinions to classmates about their feelings and emotions.

\section{Class Opinions (CO)}

The main source of data for this category was the semi-interviews implemented at the end of first and third intervention. Students were asked certain questions. In the first question, they had to say their thoughts about the class given and the second question was about what they liked the most from the class. The majority of students expressed that classes were excellent and interesting. S1 said "this class helped us to learn much more". S4 also said "classes were very good". $\$ 4$ expressed that the class was "excellent and varied".

Based on these facts, concluded that from the communicative activities implemented, students were more receptive to group work, opinion sharing, and information gap. 


\subsection{Results of research question two}

Research question two investigated students' attitudes when developing communicative activities in the classroom. Two major categories answered this question (all the categories can be seen in table 5). The categories were: 1) disposition to participate (DPT) and 2) interaction in the target language (ITL).

\section{Disposition to Participate (DPT)}

It is worth to point out that the majority of students showed a great disposition to participate during the interventions. The structured interviews included the following question: when activities are done in the classroom, what do you do? Most of students said they participated while a minority said they didn't like it or they didn't participate. During the class observations also noticed that students collaborated in the actives but there were certain activities in which some students showed resistance.

When the vocabulary was provided, we used to do choral repetitions to which students responded positively. In the third intervention, students were laughing when reenacting the animal sounds in intervention one. They seemed amused at the moment of doing a dialogue with a classmate. When we had to do an activity that they didn't understand, they asked me what they had to do (in their mother tongue) or they also expressed literally that they didn't understand.

\section{Interaction in the Target Language (ITL)}

It was fundamental to know the attitudes and feelings of students when speaking English in the classroom. For these reason there was a question which was the same in the structured and semi-structured interviews. They had to answer how they felt when they spoke English in the classroom. In the structured interviews, forty percent of the students said they felt nervous while in the structured, thirty percent expressed that although they spoke, they still felt nervous. See some of the semi-structured interviews' answers in the following table.
Table 8. Students' feelings when speaking English

\begin{tabular}{cl}
\hline Student (S) & $\begin{array}{l}\text { Answers (Semi-structured Inter- } \\
\text { views) }\end{array}$ \\
\hline S3 & "I was fine" \\
\hline S5 & "I felt a little shy" \\
\hline S6 & "very well" \\
\hline S7 & $\begin{array}{l}\text { "at the beginning I was a bit ner- } \\
\text { vous" }\end{array}$ \\
\hline S9 & "I felt just fine" \\
\hline
\end{tabular}

Note: Created by researchers.

I tried to speak English the whole time during the three interventions although some students relied on their mother tongue. I remember that at the beginning of intervention some students seemed to be confused but after a while, they started to respond and use the target language. An example was intervention two where students started greeting me in English and this time they didn't seem confused as in the prior session.

Students' reactions and attitudes were more positive than negative. They had a good connection, almost everyone was eager to participate, many hands up, and we created a nice environment. Despite certain negativism in session two, all over the sessions some students laughed, had fun and some of them controlled to a decent degree their anxiety of speaking in the target language.

\subsection{Results of research question three}

Research question three investigated new strategies that could be used to have successful communicative activities in the classroom. To answer this question, two umbrella categories emerged (all the categories can be seen in table 5). These categories were: 1) teaching strategies (DPT) and 2) students' leaning preferences (SLP).

\section{Teaching Strategies (TS)}

The information on this category mostly came from the class observations. At the beginning of class session one, students were lost but after I showed 
them pictures about the topic (the greetings), their faces seemed to be less confused and more positive. Some students were totally dependent on the mother tongue and that forced me to use Spanish in certain moments which resulted beneficial because these students, who had difficulties, integrated to the class activity. In the second session, there was an activity where students had to stand up, exchange information with a classmate, and report to the whole class. I had to repeat instructions and give examples three times for them to start doing it. Based on the previously stated information, I concluded that repetition and examples were necessary to a great extent with these students.

I had to moderate my speech speed in the second session because the topic was more complicated than in the first session. I also implemented the rule of telling students the time they had for each activity for them to be aware of, the time limit. This strategy worked well because students stayed active and attentive to the class.

\section{Students' Learning Preferences (SLP)}

The semi-structured interviews were fundamental in the creation of these categories because they included a question that directly asked them the type of activity they would like to do in the following session. Although this question was related to the type of activities they preferred, this helped me prepare for the next sessions in which I had to think not only about the activity but the strategies I would use during the activity.

\section{Conclusions and discussion}

At the end of this investigation, after applying the necessary data collecting tools and the results obtained, it was visible that group work was the communicative activity that worked best with sixth-grade students. They were focused and positive minded. Teachers should implement group work activities because according to Kwon (2017), through them the communicative competence is developed. Although it is worth to point out that the Dominican culture is dynamic and people like to be together. With that,
I could say that culture and context could affect the effectiveness of group work just as Owen and Razali (2018) stated. Opinion sharing activities were engaging and students felt motivated to participate, although they had limited vocabulary they wanted to give their opinion about the topic which in this case was "feelings and emotions". The Information gap activity was productive as students got engaged in searching for their partners' information. Although students were more receptive to group work, opinion sharing, and information gap activities, the information transfer and mingle activities didn't work that well with them.

These activities resulted more effective than the traditional ones because students had significant learning but as Ahmad and Rao (2012) stated, they should be conducted carefully and above all, they should be focused on students' interests. This means we could plan a good activity which might not work if it is not planned according to the local context. The study results also correlated with those of Ahmad and Rao (2013) because the implementation of communicative activities delivered better results than the traditional ones.

In regard to attitudes while developing the activities, students were receptive to a great extent. There was collaboration and willingness to participate throughout the different sessions. Students started using the target language. I also noticed that students saw the activities the way the teacher projected it. The teacher needs to be positive and believe in the activities he/she is doing because students can perceive the attitude of the teacher and adopt it (Denkci Akkas $\&$ Coker, 2016). In a general aspect, there was acceptance to the communicative activities from most of students. Nevertheless, it is important to mention that there were times when some students got frustrated when they did not understand what to do in a certain activity. There were some of them who said they were not going to participate. This didn't happen as a general phenomenon but on a minimal scale during sessions (Chan, 2010). It is worth to mention that the results showed that some students felt anxiety when speaking the target language and this 
is something to take into account when assigning activities in which students might have to speak in public or report in front of the whole class.

Different teaching strategies were used throughout the sessions when communicative activities were developed and the class was mainly conducted in the target language. Modeling was a solution to overcome the linguistic gaps that emerged. It helped sixth-grade students understand what they had to do when they had some modeling from the teacher. Clear instruction was necessary, but modeling just one time was not enough, two or three times with different examples was more appropriate because repetition was the key (Kwon, 2017). Another strategy that worked well was to give students enough time to develop their activities but always letting them know that they had a limit of time; this let them realize that they had to work with a certain pace because every activity had an time limit (Algwil, 2019).

Most modern methods and approaches recommend using the target language $100 \%$ of the time since the beginning but with my students, starting with the target language worked better. Permitting the mother tongue was beneficial, but, as stated by Littlewood et al. (2009), teacher should be careful not to make students dependent on the mother tongue.

Using appropriate resources (realia) was a strategy that worked well with sixth-grade students. Pictures played an important role in the sessions as they helped students understand in a faster and effective way the topics. Although in the sessions, videos were not used, it would have been a great resource to integrate as it could have maximized students' learning experience (Denkci Akkas \& Coker, 2016).

It is worth to point out the limitations of the research. This study was carried out only with a specific group which means results may vary from group to group. As it was stated above, the context plays an important role when implementing the communicative approach. Besides the context, there is a series of factors that may also influence the results of each research. Factors such as the amount of teaching time, the socio-economical background, teaching resources, teachers' attitudes, general perceptions toward the target language, and others.

More research is needed in regard to the topic in our local context. A way to facilitate such studies is if the Ministry of Education (MINERD) and the Ministry of Superior Education (MESCYT) encourage teachers and professors to do so. I recommend to create a program or a contest where teachers could be nationally recognized for their investigations. I also recommend teachers to start implementing the communicative approach in their classrooms because the results are gratifying. A final recommendation for all Education Ministries is to create teaching training programs because as reported by some researchers, most of the time new methods or approaches don't work based of the lack of experience or training the teacher has in regard to it.

\section{Bibliographic references}

Ahmad, S., \& Rao, C. (2012). Does it Work? Implementing Communicative Language Teaching Approach in EFL Context. Journal of Education and Practice, 3(12), 28-35. http://bit.ly/388QF0s

Ahmad, S., \& Rao, C. (2013). Applying the Communicative Approach in Teaching English as a Foreign Language: A Case Study of Pakistan. Porta Linguarum, 187-203. http://bit.ly/2 $\mathrm{NxOjAk}$

Algwil, K. (2019). The application of the communicative language teaching method in the Libyan class at a UK university: Lesson Plan, Rationale and Evaluation. PUPIL: International Journal of Teaching, Education and Learning, 3(1), 245-257.

https://dx.doi.org/10.20319/pijtel.2019.31.245257

Arzamendi, J., Ball, P., \& Gassó, E. (2016). Methodological Approaches. Formación Universitaria. Fundación Barcelona: FUNIBER.

Chan, L. H., \& Chen, C. H. (2010). Conflict from teamwork in project-based collaborative learning. Performance Improvement, 49(2), 23-28.

Crystal, D. (2012). English as a Global Language. 
Cambridge: Cambridge University Press. http://bit.ly/3bm35nY

Denkci Akkas, F., \& Coker, B. (2016). The use of communicative approach in 9th grade EFL classes. Eurasian Journal of Educational Research, 65, 71-90. http://r.issu.edu.do/l.php?l=225xa9

Hernández Sampieri, R., Fernández Collado, C., \& Baptista Lucio, P. (2014). Metodología de la investigación (6a. ed.). México: McGraw-Hill.

Herouach, S., Hicham, L., Lahmar, B., \& Bensehra, M. (2020). Applying the Communicative Approach in Teaching English Language: Impediments and challenges, Taza and Taounante Regions as Case Studies. International Journal of Contemporary Research and Review, 11(01), 20674-20692. https://doi.org/10.15520/ijcrr.v11i01.774

Kemmis, S., McTaggart, R., \& Nixon, R. (2014). The Action Research Planner: Doing Critical Participatory Action Research. Singapore: Springer. http://dx.doi.org/10.1007/978-981-4560-67-2

Kwon, J. (2017). Immigrant mothers' beliefs and transnational strategies for their children's heritage language maintenance. Language and Education, 31(6), 495-508.

Larsen-Freeman, D., \& Anderson, M. (2011). Techniques and Principles in Language Teaching (3rd Ed.). Oxford: Oxford University Press. http://bit.ly/2RthZzy

Littlewood, W., \& Yu, B. (2009). First language and target language in the foreign language classroom. Language Teaching, 42(04), 64-77.

https://doi.org/10.1017/S0261444809990310

Madrid, D. (2016). Observation and Research in the Language Classroom. Barcelona: Funiber.

Malik, A., \& Gunawan, M. I. (2018). To What Extent the Use of Communicative Approach in the Teaching of English as a Foreign Language by Teachers of Senior High Schools in Bengkalis. Inovish Journal, 3(2), 230-244.

https://dx.doi.org/10.35314/inovish.v3i2.823
McNiff, J. (2017). Action Research: All You Need to Know. London: Sage Publications.

http://bit.ly/37y6Mno

Muhassin, M. (2016). Teachers' Communicative Activities in Teaching English as A Foreign Language (Tefl): A Study at Sman 9 Bandar Lampung. Humaniora, 7(4), 485-492.

https://doi.org/10.21512/humaniora.v7i4.3601

Neuman, W. L. (2014) Social Research Methods: Qualitative and Quantitative Approaches (7th Ed.). Edinburgh: Pearson. http://bit.ly/2uahLWk

Nyinondi, O. S., Mhandeni, A. S., \& Mohamed, H. I. (2017). The use of communicative language teaching approach in the teaching of communication skills courses in Tanzanian universities. International Journal of Research Studies in Language Learning, 6(3), 89-99. https://doi.org/10.5861/ijrsll.2016.1528

Owen, E. A., \& Razali, A. B. (2018). The Effect of Communicative Activities on Libyan Secondary School Students' Speaking Performance in Malaysia. International Journal of Instruction, 11(4), 45-60. http://dx.doi.org/10.12973/iji.2018.1144a

Prabhu, N. S. (1987). Second language pedagogy (Vol. 20). Oxford: Oxford University Press.

Rahmawati, Y. (2018). Teachers' perspective on the implementation of Communicative Approach in Indonesian classrooms. IJEE. Indonesian Journal of English Education, 5(1).

https://doi.org/10.15408/ijee.v5i1.9881

Richards, J. C., \& Rodgers, T. S. (2014). Approaches and methods in language teaching. Cambridge: Cambridge University Press. http://bit.ly/2tgPIo3

Savignon, S.J. (2017). Communicative Competence. In J. I. Liontas \& M. DelliCarpini (Eds.). The TESOL Encyclopedia of English Language Teaching. https://doi.org/10.1002/9781118784235.eelt0047

Vongxay, H. (2013). The Implementation of Communicative Language teaching (CLT) in an English Department in a Lao Higher Educational Institution: 


\section{MARTÍNEZ-GÓMEZ}

Transitioning to communicative activities in teaching english as a foreign language...

A Case Study (Master Thesis). New Zealand: Unitec Institution of Technology. http://bit.ly/2SQlznY

Wan, Y. S. (1990). Drama in Teaching English as a Second Language - A Communicative Approach. The English Teacher, 19, 1-13.

http://r.issu.edu.do/l.php?l=226ASa
Zorrilla Duvergé, D. (Coord.). (2014). Categorización por cargos docentes en el contexto del desarrollo de la carrera docente en la República Dominicana. Una perspectiva de horizontalidad. República Dominicana: Ministerio de Educación.

\section{CÓMO CITAR:}

Martínez-Gómez, A. (2020). Transición a actividades comunicativas en la enseñanza de Inglés como Lengua Extranjera en la República Dominicana. Revista Caribeña de Investigación Educativa (RECIE), 4(2), 159-171. https://doi.org/10.32541/recie.2020. v4i2.pp159-171 